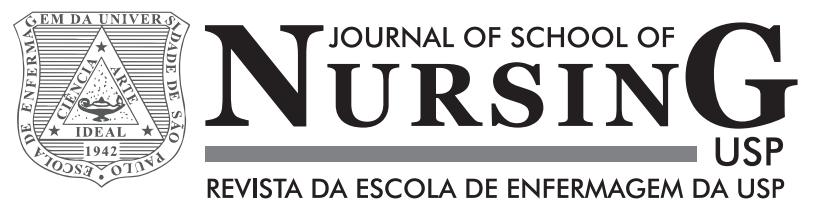

\title{
Glycemic control strategies and the occurrence of surgical site infection: a systematic review
}

\author{
Estratégias de controle glicêmico e a ocorrência de infecção \\ do sítio cirúrgico: revisão sistemática \\ Estrategias de control glicémico y la ocurrencia de infección \\ del sitio quirúrgico: revisión sistemática
}

\section{Caroline Maria Herrero Domingos ${ }^{1}$, Luciana Inaba Senyer lida², Vanessa de Brito Poveda ${ }^{3}$}

\section{Como citar este artigo:}

Domingos CMH, Iida LIS, Poveda VB. Glycemic control strategies and the occurrence of surgical site infection: a systematic review. Rev Esc Enferm USP. 2016;50(5):868-874. DOI: http://dx.doi.org/10.1590/S0080-623420160000600022

\author{
${ }^{1}$ Universidade de São Paulo, Hospital \\ Universitário, São Paulo, SP, Brazil. \\ ${ }^{2}$ Universidade de São Paulo, Hospital \\ Universitário, Serviço de Ensino e \\ Qualidade, São Paulo, SP, Brazil. \\ ${ }^{3}$ Universidade de São Paulo, Escola de \\ Enfermagem, Departamento de Enfermagem \\ Médico-Cirúrgica, São Paulo, SP, Brazil.
}

\begin{abstract}
Objective: To analyze the available evidence in the scientific literature on the relationship between glycemic control strategies performed and the occurrence of surgical site infection in adult patients undergoing surgery. Method: This is a systematic review, through the CINAHL, Medline, LILACS, Cochrane Database of Systematic Reviews, and EMBASE, which included 8 studies. Results: Despite the diversity of tested interventions, studies agree that glycemic control is essential to reduce surgical site infection rates and should be kept between 80 and $120 \mathrm{mg} / \mathrm{dl}$ during the perioperative period. Insulin continuous infusion during surgery was the most tested and seems to get better results in reducing surgical site infection rates and success in glycemic control compared to other strategies. Conclusion: Strict glycemic control during the perioperative benefits the recovery of surgical patients, especially for the successful implementation of the measure the performance of the nursing team.
\end{abstract}

\section{DESCRIPTORS}

Surgical Wound Infection; Glycemic Index; Perioperative Nursing; Review. 


\section{INTRODUCTION}

Healthcare-associated infections (HAIs) are a major cause of morbidity and mortality, and consequently of higher care costs. HAIs are those acquired after patient's hospital admission, and manifested during hospitalization or after discharge, when related to hospitalization or hospital procedures ${ }^{(1)}$.

In Brazil, surgical site infections (SSI) ranks third among the HAIs ${ }^{(1)}$. In 2013, in the state of São Paulo, among the 514 hospitals that performed more than 250 clean surgeries per month such as cardiac, neurological and orthopedic surgery, there was a median of $0.48 \%$ cases of $\mathrm{SSI}^{(2)}$.

SSIs are the main causes of complications among patients undergoing surgical procedures, increasing hospital length of stay and costs, and also causing physical and emotional damage to patients ${ }^{(3-7)}$.

SSIs affect the surgical wound and are classified according to the topography. It is considered superficial incisional SSI (SI - SSI) if occurrence is in the first 30 days after surgery, and involves only skin and subcutaneous tissue; it is deep incisional SSI (DI - SSI) when deep soft tissues are affected, and occurrence within 30 days after surgery, or even after a year in cases of prosthetic implants; finally, it is organ/space SSI (OS - SSI) when identified in the first 30 days after surgery, or even after a year, and affects organs or cavities manipulated during surgery ${ }^{(1)}$.

In a recent recommendation, the Centers for Disease Control and Prevention (CDC) suggested changing the surveillance period of deep and organ and/or space infections for the maximum of 90 days, replacing the earlier recommended period of one year ${ }^{(4)}$.

Some intrinsic and extrinsic factors to patients can be crucial for the occurrence of SSIs. They are related to the procedure to be performed, such as type of surgery, its duration, employed techniques, preoperative preparation, and factors related to inoculum of microorganisms, such as their virulence and resistance originating from the environment and the patient's microflora. There are also factors related to patients themselves, as extremes of age, smoking, obesity, malnutrition, use of immunosuppressive drugs, and the presence of chronic diseases such as diabetes mellitus (DM) and hyperglycemia, which motivated this study ${ }^{(3-7)}$.

In this sense, with significant improvements in quality of life and technological advances, combined with higher survival, there is increased population with chronic diseases (such as diabetes mellitus) that will undergo surgical procedures. Therefore, many chronic diseases need to be stabilized for a successful surgical intervention, i.e., to minimize the occurrence of risks ${ }^{(3,5,7-9)}$.

Coupled with DM, hyperglycemia is a frequent problem encountered in patients in critical condition and/ or undergoing surgical procedures. It is a cause of morbidity and mortality due to physiological abnormalities of healing, vascular and neuropathic complications, and inhibition of these individuals' defense system, making them more aggressively exposed to the risk of SSIs ${ }^{(10-11)}$.

Hyperglycemia can be defined as the abnormal increase in blood glucose levels, greater than $140 \mathrm{mg} / \mathrm{dL}$ in patients with no history of diabetes or absence of changes in glycated hemoglobin levels ${ }^{(10-11)}$.

The aim of the present study was to analyze the available evidence in the scientific literature regarding the relationship between glycemic control strategies used and the occurrence of surgical site infection in adult patients undergoing surgery, and identify gaps in the scientific knowledge produced so far to point recommendations for future research.

\section{METHOD}

A systematic review (SR) of literature was conducted with the aim to identify the studies with best methodological quality that can bring evidence for the improvement of health care practices by assisting in decision making, and that are also relevant tools for scientific investigation $^{(12-13)}$.

The following steps were established to perform this systematic review: definition of the research question; search for evidence in the literature; revision and selection of studies according to the inclusion and exclusion criteria; analysis, synthesis and presentation of results ${ }^{(12-13)}$.

The PICO strategy was used to elaborate the research question (Chart 1$)$.

Chart 1 - PICO strategy - São Paulo, SP, Brazil, 2016.

\begin{tabular}{|l|l|}
\hline P (patient) & Adult surgical patient \\
\hline I (intervention) & Perioperative glycemic control \\
\hline C (control) & Usual care \\
\hline O (outcome) & Occurrence of surgical site infection \\
\hline
\end{tabular}

The guiding question of the systematic review was: What is the relationship between blood glucose control strategies used perioperatively with adult surgical patients and the occurrence of SSI?

The following databases were used to search for the studies included in the systematic review: Cumulative Index to Nursing and Allied Health Literature (CINAHL); Medical Literature Analysis and Retrieval System Online (MEDLINE); Latin American and Caribbean Health Sciences (LILACS); Cochrane Database of Systematic Reviews (CDSR, Cochrane Reviews); EMBASE.

After selection of the articles included in the review, was performed a careful analysis of the references listed in these studies to identify new references that may not have been located by the initial strategy organized (gray literature). Thus, to perform the search, the controlled and uncontrolled descriptors were combined as follows (Chart 2): 
Chart 2 - Distribution of search strategies according to the database and number of articles located - São Paulo, SP, Brazil, 2016.

\begin{tabular}{|c|c|c|}
\hline Database & Search & $\begin{array}{c}\text { Retrieved } \\
\text { articles }\end{array}$ \\
\hline PUBMED & 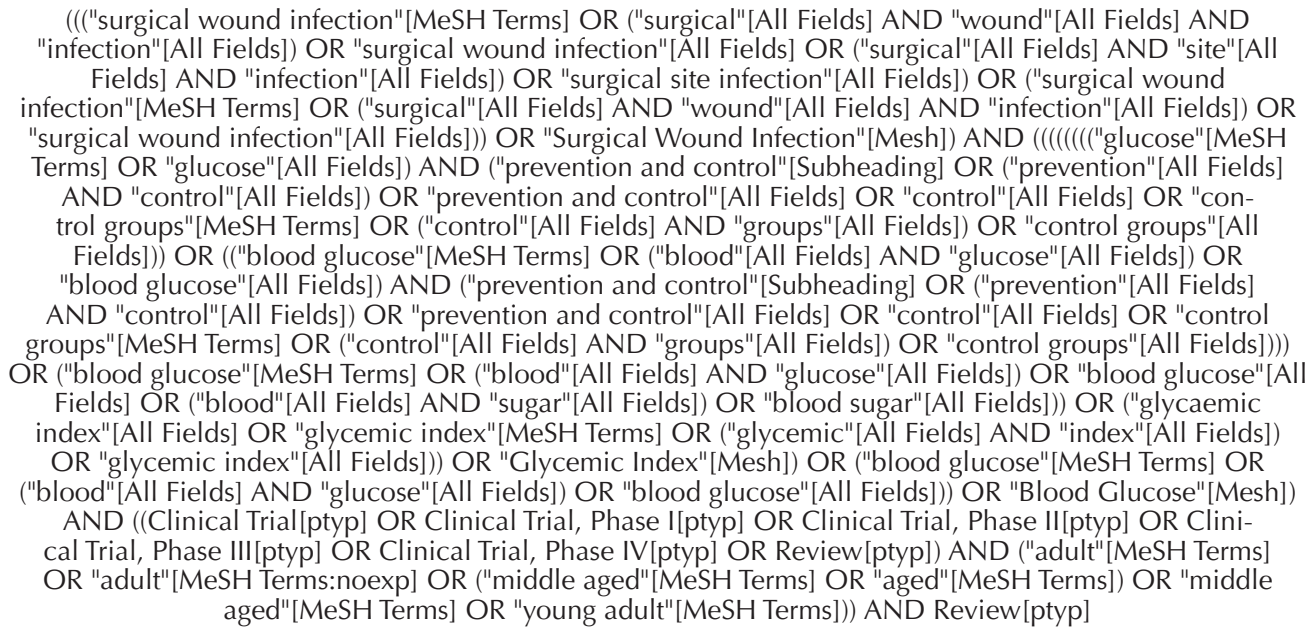 & $\mathrm{n}=40$ \\
\hline CINAHL & $\begin{array}{c}\text { (MH "Glycemic Control") OR "glycemic control" OR "glucose control" OR (MH "Blood Glucose") OR (MH } \\
\text { "Blood Glucose Monitoring") OR "blood glucose control" OR "blood sugar" OR (MH "Surgical Wound Infec- } \\
\text { tion") AND "surgical wound infection" OR "surgical site infection" }\end{array}$ & $\mathrm{n}=86$ \\
\hline LILACS & "infecção da ferida operatória" [subject descriptor] AND "índice glicêmico" [subject descriptor] & $\mathrm{n}=0$ \\
\hline EMBASE & $\begin{array}{c}\text { 'blood'/exp OR blood AND ('glucose'/exp OR glucose) OR 'blood'/exp OR blood AND ('sugar'/exp OR } \\
\text { sugar) OR 'blood'/exp OR blood AND ('glucose'/exp OR glucose) AND ('control'/exp OR control) OR } \\
\text { 'glycemia'/exp OR glycemia AND index OR 'glucose'/exp OR glucose AND ('control'/exp OR control) AND } \\
\text { surgical AND ('wound'/exp OR wound) AND ('infection'/exp OR infection) OR surgical AND site AND } \\
\text { ('infection'/exp OR infection) AND ([young adult]/lim OR [adult]/lim OR [middle aged]/lim OR [aged]/lim) } \\
\text { AND [humans]/lim AND [embase]/lim }\end{array}$ & $\mathrm{n}=501$ \\
\hline Cochrane & $\begin{array}{l}\text { 'Blood Glucose' or 'Glycemia Index' or 'Blood sugar' or 'Blood glucose control' or 'Glucose control' and } \\
\text { 'Surgical Wound Infection' or 'surgical site infection' }\end{array}$ & $\mathrm{n}=248$ \\
\hline
\end{tabular}

The systematic review included randomized controlled trials that analyzed different glycemic control strategies in the perioperative period used with patients aged 18 years or over and their relationship with the occurrence of SSI, published in English, Spanish and Portuguese, from the indexing date in the investigated databases until December $12^{\text {th }}, 2015$.

The following articles were excluded: those on glycemic control procedures in patients who did not undergo surgery; those testing interventions in animals or in laboratory; and those using only one dietary control strategy for blood glucose regulation.

The extraction of data from the studies included in the review was performed by two reviewers independently, using the Jadad et al. score to assess the quality of randomized controlled trials ${ }^{(14)}$.

The synthesis of data from the studies included in the systematic review was performed descriptively, including information such as sample size, the implemented and measured intervention, the statistical analysis adopted, and the main results. For a better understanding of results, were established categories according to similarity of tested interventions, i.e., studies testing the management of blood glucose by intravenous insulin infusion, and studies testing the subcutaneous administration of insulin.

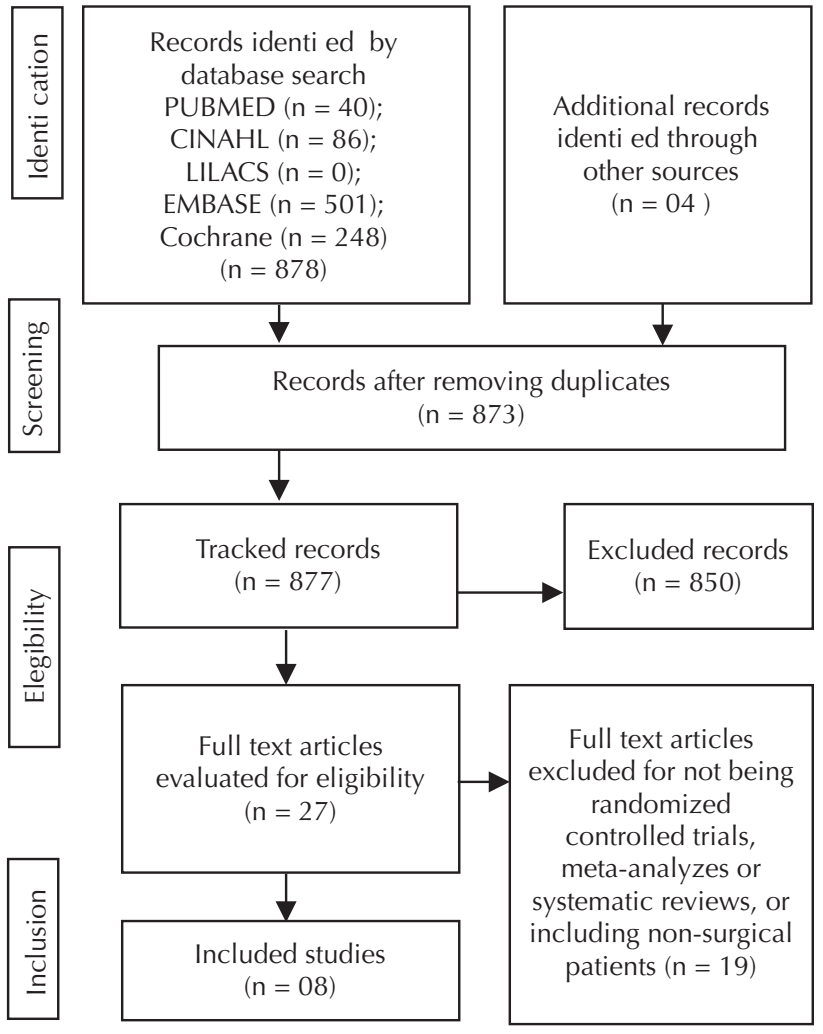

Figure 1 - Flowchart for selection of articles included in the review - São Paulo, SP, Brazil, 2016. 


\section{RESULTS}

Eight randomized clinical trials were included in this review, all published in English in journals such as Diabetes Care $(\mathrm{n}=2)$, Anesthesiology, Annals of Internal Medicine, Circulation, Endocrine Practice, Journal of Neurosurgery Anesthesiology, and Texas Heart Institute Journal. Most investigations were produced in the United States of America (USA) $(n=4)$, followed by Japan $(\mathrm{n}=2)$, Italy $(\mathrm{n}=1)$ and China $(\mathrm{n}=1)$.

The studies addressed different types of surgical specialties such as general surgery, gastrointestinal, vascular and heart surgery, and the study groups included diabetic and nondiabetic patients, with samples ranging between 41 and 447 subjects $^{(15-22)}$.

Regarding methodological quality of the analyzed studies, their scores ranged from 1 to 3 , which shows low or moderate methodological quality ${ }^{(15-22)}$.

Table 3 presents a summary of the studies included in this systematic review, its main results and conclusions, according to the categories of intravenous insulin infusion and subcutaneous administration of insulin.

The category of intravenous insulin infusion included seven studies that used continuous infusion of insulin, compared to different forms of glycemic control focused on maintaining the blood glucose below $200 \mathrm{mg} / \mathrm{dL}$, preferably with values below $150 \mathrm{mg} / \mathrm{dL}$, which had higher association with reduced rates of SSI and/or several other outcomes ${ }^{(15-21)}$. Among the seven studies included in this category, only two ${ }^{(17,19)}$ revealed no statistically significant associations between continuous infusion of insulin and the occurrence of SSI. However, it stands out that both studies address the comparison of continuous infusion and bolus infusion of insulin (Chart 3).

According to the included studies, maintenance of glycemia should be a goal during the perioperative period. Regarding the benefit of continuous infusion of insulin, there seems to be a trend of superiority in preventing SSI and other outcomes, but there is a wide range of tested interventions, different cutoff values related to glucose and diversity at the time of starting the intervention ${ }^{(15-21)}$.

Only one study examined the glycemic control intraoperatively by subcutaneous regular insulin administration, and found that a more rigorous control of blood sugar, keeping it between 80 and $110 \mathrm{mg} / \mathrm{dL}$, was associated with reduced SSI rates and decreased hospitalization period ${ }^{(22)}$.

Note that studies included in this review emphasized the possible increased incidence of comorbidities postoperatively caused by hyperglycemia, such as dehiscence, fistulas, bacteremia, renal failure, urinary tract and bloodstream infections, and increased SSI rates ${ }^{(15-16,18-22)}$.

Chart 3 - Summary of the studies included in the systematic review according to type of patient, study groups, results and conclusions - São Paulo, SP, Brazil, 2016.

\begin{tabular}{|c|c|c|c|c|c|c|}
\hline \multicolumn{7}{|c|}{ Intravenous administration of insulin } \\
\hline Study & Sample & $\begin{array}{c}\text { Type of surgery/ } \\
\text { patient }\end{array}$ & Intervention group (IG) & Control group (CG) & Result/Conclusion & Jadad \\
\hline $\begin{array}{l}\text { Li et al., } \\
2006^{(15)}\end{array}$ & $n=93$ & $\begin{array}{l}\text { Coronary bypass/ } \\
\text { Diabetic and } \\
\text { nondiabetic patients }\end{array}$ & $\begin{array}{l}\text { IPO: Continuous IV } \\
\text { infusion of insulin } \\
\quad(\mathrm{n}=51)\end{array}$ & $\begin{array}{l}\text { IPO: Subcutaneous } \\
\text { regular insulin by } \\
\text { glucometer }(n=42)\end{array}$ & $\begin{array}{l}\text { IG was associated with } \\
\text { lower SSI rates }\end{array}$ & 2 \\
\hline $\begin{array}{l}\text { Okabayashi } \\
\text { et al., 2009(16) }\end{array}$ & $\mathrm{n}=88$ & $\begin{array}{c}\text { Surgical resection } \\
\text { of liver/ } \\
\text { Diabetic patients }\end{array}$ & $\begin{array}{l}\text { IPO: Continuous IV } \\
\text { infusion of insulin } \\
\quad(\mathrm{n}=44)\end{array}$ & $\begin{array}{l}\text { IPO: Tight glucose } \\
\text { control by subcutaneous } \\
\text { regular insulin } \\
\text { administration }(n=44)\end{array}$ & $\begin{array}{l}\text { IG was associated with } \\
\text { lower SSI rates and costs }\end{array}$ & 1 \\
\hline $\begin{array}{l}\text { Subramaniam } \\
\text { et al., } 2009^{(17)}\end{array}$ & $n=236$ & $\begin{array}{l}\text { Vascular surgery/ } \\
\text { Diabetic and } \\
\text { nondiabetic patients }\end{array}$ & $\begin{array}{l}\text { IO: Continuous IV } \\
\text { infusion of insulin to } \\
\text { maintain blood glucose } \\
\text { between } 100 \text { and } \\
150 \mathrm{mg} / \mathrm{dL}(\mathrm{n}=114)\end{array}$ & $\begin{array}{l}\text { IO: IV bolus infusion } \\
\text { of insulin to maintain } \\
\text { blood glucose lower } \\
\text { than } 150 \mathrm{mg} / \mathrm{dL} \\
\quad(\mathrm{n}=122)\end{array}$ & $\begin{array}{l}\text { IG obtained fewer } \\
\text { cardiovascular effects, but } \\
\text { there was no statistically } \\
\text { significant difference for SSI } \\
\text { between the study groups }\end{array}$ & 3 \\
\hline $\begin{array}{l}\text { Bilotta et al., } \\
2007^{(18)}\end{array}$ & $\mathrm{n}=78$ & $\begin{array}{l}\text { Brain aneurysm } \\
\text { surgery/ } \\
\text { Diabetic patients }\end{array}$ & $\begin{array}{l}\text { IO: Continuous IV } \\
\text { infusion of insulin to } \\
\text { maintain blood glucose } \\
\text { between } 80 \text { and } \\
120 \mathrm{mg} / \mathrm{dL}(\mathrm{n}=40)\end{array}$ & $\begin{array}{c}\text { IO: continuous IV } \\
\text { infusion of insulin to } \\
\text { maintain blood glucose } \\
\text { between } 80 \text { and } 220 \\
\mathrm{mg} / \mathrm{dL}(\mathrm{n}=38)\end{array}$ & $\begin{array}{l}\text { IG was associated with } \\
\text { lower rates of urinary tract } \\
\text { infection, } \\
\text { pneumonia and SSI }\end{array}$ & 3 \\
\hline $\begin{array}{l}\text { Gandhi et al., } \\
2007^{(19)}\end{array}$ & $n=371$ & $\begin{array}{l}\text { Cardiac surgery/ } \\
\text { Diabetic and } \\
\text { nondiabetic patients }\end{array}$ & $\begin{array}{l}\text { IO: Continuous IV } \\
\text { infusion of insulin to } \\
\text { maintain blood glucose } \\
\text { between } 80 \text { and } \\
100 \mathrm{mg} / \mathrm{dL}(\mathrm{n}=185)\end{array}$ & $\begin{array}{l}\text { IO: IV bolus infusion } \\
\text { of insulin when blood } \\
\text { glucose } \geq 200 \mathrm{mg} / \mathrm{dL} \\
\qquad(\mathrm{n}=186)\end{array}$ & $\begin{array}{l}\text { There was no } \\
\text { difference between the } \\
\text { study groups regarding the } \\
\text { occurrence of SSI, heart } \\
\text { failure, kidney failure and } \\
\text { death }\end{array}$ & 3 \\
\hline $\begin{array}{l}\text { Lazar et al., } \\
\qquad 2004^{(20)}\end{array}$ & $\mathrm{n}=141$ & $\begin{array}{l}\text { Coronary artery } \\
\text { bypass surgery/ } \\
\text { Diabetic patients }\end{array}$ & $\begin{array}{l}\text { IO: IV infusion of } \\
\text { glucose, regular insulin } \\
\text { and potassium }(n=72)\end{array}$ & $\begin{array}{l}\text { IO: IV infusion of } \\
\text { glucose solution } \\
\quad(\mathrm{n}=69)\end{array}$ & $\begin{array}{l}\text { IG was associated with } \\
\text { lower rates of } \\
\text { pneumonia and SSI }\end{array}$ & 1 \\
\hline $\begin{array}{l}\text { Grey et al, } \\
2004^{(21)}\end{array}$ & $\mathrm{n}=61$ & $\begin{array}{l}\text { General surgery/ } \\
\text { Diabetic patients }\end{array}$ & $\begin{array}{l}\text { PO: Continuous IV } \\
\text { infusion of insulin to } \\
\text { maintain blood glucose } \\
\text { between } 80 \text { and } 120 \\
\mathrm{mg} / \mathrm{dL}(\mathrm{n}=27)\end{array}$ & $\begin{array}{l}\text { PO: Continuous IV } \\
\text { infusion of insulin to } \\
\text { maintain blood glucose } \\
\text { between } 180 \text { and } 220 \\
\mathrm{mg} / \mathrm{dL}(\mathrm{n}=34)\end{array}$ & $\begin{array}{l}\text { IG was associated with } \\
\text { lower rates of bloodstream } \\
\text { infections and SSIs }\end{array}$ & 2 \\
\hline
\end{tabular}




\begin{tabular}{|c|c|c|c|c|c|c|}
\hline \multicolumn{7}{|c|}{ Subcutaneous administration of insulin } \\
\hline Study & Sample & $\begin{array}{c}\text { Type of surgery/ } \\
\text { patient }\end{array}$ & Intervention group (IG) & Control group (CG) & Result/Conclusion & Jadad \\
\hline $\begin{array}{l}\text { Okabayashi } \\
\text { et al., 2014 }\end{array}$ & $n=447$ & $\begin{array}{l}\text { Surgical resection of } \\
\text { pancreas and/or liver/ } \\
\text { Diabetic patients }\end{array}$ & $\begin{array}{l}\text { IO: Tight glycemic } \\
\text { control of } 4.4-6.1 \mathrm{mmol} / \mathrm{L} \\
\text { (80-110 mg/dL) using } \\
\text { subcutaneous regular } \\
\text { insulin }(\mathrm{n}=222)\end{array}$ & $\begin{array}{c}\text { IO: Glycemic control of } \\
7.7-10.0 \mathrm{mmol} / \mathrm{L}(140- \\
180 \mathrm{mg} / \mathrm{dL}) \text { using subcu- } \\
\text { taneoous regular insulin } \\
(\mathrm{n}=225)\end{array}$ & $\begin{array}{l}\text { IG was associated with lower } \\
\text { SSI rates and decreased } \\
\text { hospital length of stay }\end{array}$ & 2 \\
\hline
\end{tabular}

Legend: IO: intraoperative; IPO: immediate postoperative period; PO: postoperative; IV: intravenous; SC: subcutaneous; SSI: surgical site infection; IG: intervention group; CG: control group.

\section{DISCUSSION}

Glycemic control is an important aspect in the prevention of surgical site infections, and occupies position of equal importance among other traditional preventive measures such as appropriate antibiotic prophylaxis, normothermia and hair removal ${ }^{(23)}$.

In addition, a recent integrative review found that 23 out of 26 studies emphasized the need for glycemic control, observing an association of hyperglycemia with infections in the postoperative period, highlighting SSIs, increased morbidity, mortality, and costs during hospitalization ${ }^{(5)}$.

A systematic review published in 2009 included only five studies and aimed to verify the relationship between glycemic control and the incidence of surgical site infections, mortality and length of hospital stay. It found a lack of evidence, demonstrating that glycemic control is sufficient for the prevention of SSIs, especially given the poor sampling of included studies and inconsistencies in the definitions of outcomes and methodological quality ${ }^{(24)}$. Compared to the review from 2009, the present systematic review reflects improvement, because it included all the previously analyzed studies, plus three new studies ${ }^{(16-17,22)}$.

Although the objective of all investigations included in this review was glycemic control, reduction in morbidity, mortality, and SSI indices, there was diversity of treatment strategies and glycemic control during the perioperative period, and variety of surgeries, and investigated samples. These aspects reflect the need for further investigations to decide clinically about the best intervention to be applied, since regardless of the method, most studies showed positive results when implementing glycemic control to reduce SSI rates.

Among the included studies, seven ${ }^{(15-21)}$ tested the use of continuous infusion of insulin compared to different glycemic control methods, and five found that continuous infusion of insulin was superior to other strategies in maintaining blood glucose levels and reducing SSI rates ${ }^{(15-16,18,20-22)}$. Only two studies have not demonstrated this association, but the control groups tested the bolus infusion of insulin, which is also the intravenous infusion of insulin ${ }^{(17,19)}$.

A retrospective study of patients undergoing oncologic gynecologic surgeries found that patients undergoing strict control of hyperglycemia in the postoperative period through intravenous infusion of insulin have developed statistically significantly less cases of SSI. This means a reduction of $35 \%$ compared to diabetic patients with blood glucose controlled by subcutaneous insulin ${ }^{(25)}$.
The studies included in this review seem to agree that maintaining blood glucose between 80 and $120 \mathrm{mg} / \mathrm{dL}$ is associated with lower rates of complications in the postoperative

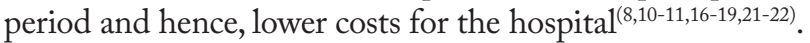

It is noteworthy that less cautious models of glycemic control were independently associated to a higher incidence of $\mathrm{SSI}^{(26)}$. In addition, investigations with different methodological designs seem to agree that maintaining blood glucose below $200 \mathrm{mg} / \mathrm{dL}^{(25,27)}$, or even below $150 \mathrm{mg} / \mathrm{dL}^{(26)}$ prevents the occurrence of SSI.

Thus, hyperglycemia is related to difficulties in the patient recovery process postoperatively, leading to subsequent limitations arising from an incomplete or inefficient healing process. The nursing team performance, particularly of nurses, is key for the appropriate preparation and administration of medication and strict control of blood glucose levels. In order to offer the best care, based on the latest scientific evidence, professionals must understand the pathophysiological process of hyperglycemia ${ }^{(28)}$.

Therefore, data presented in this review suggest the importance of tight glycemic control of patients in the perioperative period, which benefits their recovery, and the continuous infusion of insulin appears to be associated with better outcomes.

\section{CONCLUSION}

Despite the diversity of tested interventions, studies agree that glycemic control is essential to reduce SSI rates and should be kept between 80 and $120 \mathrm{mg} / \mathrm{dL}$ during the perioperative period.

The continuous infusion of intravenous insulin during surgery was the most tested, and compared to other strategies, it seems to get better results in reducing SSI rates and for the successful glycemic control.

Nursing plays a vital role in the proper implementation of glycemic control measures, actively participating since the measurement of blood glucose until the correct and accurate administration of insulin to correct hyperglycemia, thus contributing directly to the quality and success of the intervention.

However, there should be a more active participation of nurses in the development of studies on the theme, by taking ownership and developing studies of good methodological quality that indicate the most appropriate and successful forms for patients' strict glycemic control, and also describing how such interventions demand nursing care. 
RESUMO

Objetivo: Analisar as evidências disponíveis na literatura científica sobre a relação entre as estratégias de controle glicêmico efetuadas e a ocorrência de infecção do sítio cirúrgico em pacientes adultos submetidos à cirurgia. Método: Trata-se de revisão sistemática, por meio das bases de dados CINAHL, MEDLINE, LILACS, Cochrane Database of Systematic Reviews e EMBASE. Resultados: Foram selecionados oito ensaios clínicos randomizados. Apesar da diversidade de intervenções testadas, os estudos concordam que o controle glicêmico é essencial para a redução das taxas de infecção do sítio cirúrgico e deve ser mantido entre 80 e $120 \mathrm{mg} / \mathrm{dL}$ durante o perioperatório. A infusão contínua de insulina no transoperatório foi a mais testada e parece obter melhores resultados na redução das taxas de infecção do sítio cirúrgico e sucesso no controle glicêmico comparada às demais estratégias. Conclusão: $\mathrm{O}$ controle glicêmico rigoroso durante o perioperatório beneficia a recuperação do paciente cirúrgico, destacando-se a atuação da equipe de enfermagem para a implantação bem-sucedida da medida.

DESCRITORES

Infecção da Ferida Operatória; Índice Glicêmico; Enfermagem Perioperatória; Revisão.

\section{RESUMEN}

Objetivo: Analizar las evidencias disponibles en la literatura científica acerca de la relación entre las estrategias de control glicémico realizadas y la ocurrencia de infección del sitio quirúrgico en pacientes adultos sometidos a la cirugía. Método: Se trata de revisión sistemática, por medio de las bases de datos CINAHL, MEDLINE, LILACS, Cochrane Database of Systematic Revierws e EMBASE. Resultados: Fueron seleccionados ocho ensayos clínicos aleatorizados. A pesar de la diversidad de intervenciones probadas, los estudios acuerdan que el control glicémico es esencial para la reducción de las tasas de infección del sitio quirúrgico y se debe mantener entre 80 y $120 \mathrm{mg} / \mathrm{dL}$ durante el perioperatorio. La infusión continua de insulina en el transoperatorio fue la más probada y parece obtener mejores resultados en la reducción de las tasas de infección del sitio quirúrgico en el control glicémico comparada con las demás estrategias. Conclusión: El control glicémico riguroso durante el perioperatorio beneficia la recuperación del paciente quirúrgico, destacándose la actuación del equipo de enfermería para la implantación exitosa de la medida.

\section{DESCRIPTORES}

Infección de Herida Operatória; Índice Glucémico; Enfermería Perioperatoria; Revisión.

\section{REFERENCES}

1. Brasil. Ministério da Saúde; Agência Nacional de Vigilância Sanitária (ANVISA). Infecção Relacionada à Assistência de Saúde (IRAS) [Internet]. Brasília; 2009 [citado 2015 ago. 17]. Disponível em: http://www.anvisa.gov.br/servicosaude/manuais/criterios_nacionais_ISC.pdf

2. São Paulo (Estado). Secretaria de Estado da Saúde, Centro de Vigilância Epidemiológica Prof. "Alexandre Vranjac", Divisão de Infecção Hospitalar. Sistema de Vigilância Epidemiológica das Infecções Hospitalares do Estado de São Paulo. Infecção hospitalar: manual de orientações e critérios diagnósticos. São Paulo; 2011.

3. Raza S, Sabik JF, Ainkaran, Blackstone EH. Coronary artery by-pass grafting in diabetics: a growing health care cost crisis. J Thorac Cardiovasc Surg. 2015;150(2):304-12.

4. Center for Disease Control and Prevention (CDC). Surgical Site Infection (SSI) Events. Atlanta: CDC; 2016.

5. Freitas PS, Romanzini AE, Ribeiro JC, Bellusse GC, Galvão CM. Controle glicêmico no perioperatório: evidência para a prevenção de infecção de sítio cirúrgico. Rev Eletr Enf [Internet]. 2013 [citado 2016 dez. 15];15(2):541-50. Disponível em: https://www.fen.ufg.br/ fen_revista/v15/n2/pdf/v15n2a29.pdf

6. Mangram AJ, Horan TC, Pearson ML, Silver LC, Jarvis WR. Guideline for prevention of surgical site infection, 1999. Infect Control Hosp Epidemiol. 1999;20(4):250-78.

7. Brasil. Ministério da Saúde; Agência Nacional de Vigilância Sanitária (ANVISA). Sítio cirúrgico: critérios nacionais de infecção relacionada à assistência à saúde. Brasília: ANVISA; 2009.

8. Sanguineti VA, Wild JR, Fain MJ. Management of postoperative complications: general approach. Clin Geriatr Med. 2014;30(2):261-70.

9. Ngwa VC, Kar S. Frailty and surgery. Br J Hosp Med (Lond). 2016;77(2):102-6.

10. Smith FG, Sheehy AM, Vincent JL, Coursin DB. Critical illness-induced dysglycaemia: diabetes and beyond. Crit Care. $2010 ; 14: 327$.

11. Viana MV, Moraes RB, Fabbrin AR, Santos MF, Gerchman F. Assessment and treatment of hyperglycemia in critically ill patients. Rev Bras Ter Intensiva. 2014;26(1):71-6.

12. Shamseer L, Moher D, Clarke M, Ghersi D, Liberati A, Petticrew M, et al. Preferred reporting items for systematic review and meta-analysis protocols (PRISMA-P) 2015: elaboration and explanation. BMJ. 2015;349:g7647.

13. Meerpohl JJ, Herrle F, Antes G, von Elm E. Scientific value of systematic reviews: survey of editors of core clinical journals. PLoS One. 2012;7(5):e35732.

14. Jadad AR, Moore RA, Caroll D, Jenkinson C, Reynolds JM, Gvaghan DJ, et al. Assessin the quality of reports of randomized clinical trials: is blinding necessary? Controled Clin Trials.1996;17(1):1-12.

15. Li JY, Sun S, Wu SJ. Continuous insulin infusion improves postoperative glucose control in patients with diabetes mellitus undergoing coronary artery bypass surgery. Tex Heart Inst J. 2006;33(4):445-51.

16. Okabayshi T, Maeda H, Sun ZL, Montgmery RA, Nishimori I, Hanazaki K. Effect of intensive insulin therapy using a closed-loop glycemic control system in hepatic resection patients: a prospective randomized clinical trial. Diabetes Care. 2009;32(8):1425-7.

17. Subramaniam B, Panzica PJ, Novack V, Mahmood F, Matyal R, Mitchell JD, et al. Continuous perioperative insulin infusion decreases major cardiovascular events in patients undergoing vascular surgery. Anesthesiology. 2009;110(5):970-7. 
18. Bilotta F, Spinelli A, Giovannini F, Doronzio A, Delfini R, Rosa G. The effect of intensive insulin therapy on infection rate, vasospasm, neurologic outcome, and mortality in neurointensive care unit after intracranial aneurysm clipping in patients with acute subarachnoid hemorrhage: a randomized prospective pilot trial. J Neurosurg Anesthesiol. 2007;19(3):156-60.

19. Gandhi GY, Nuttall GA, Abel MD, Mullany CJ, Schaff HV, O'Brien PC, et al. Intensive intraoperative insulin therapy versus conventional glucose management during cardiac surgery. Ann Intern Med. 2007;146(4):235-43.

20. Lazar HL, Chipkin SR, Fitzgerald CA, Bao Y, Cabral H, Apstein CS. Tight glycemic control in diabetic coronary artery bypass graft patients improves perioperative outcomes and decreases recurrent ischemic events. Circulation. 2004;109(12):1497-502.

21. Grey NJ, Perdrizet GA. Reduction of nosocomial infections in the surgical intensive-care unit by strict glycemic control. Endocr Pract. 2004;10 Suppl 2:46-52.

22. Okabayashi T, Shima Y, Sumiyashi T, Kazuki A, Takumaru T, liyama T, et al. Intensive versus intermediate glucose control in surgical intensive care unit patients. Diabetes Care. 2014;37(6):1516-24.

23. Tanner J, Padley W, Assadian O, Leaper D, Kiernan M, Edmiston C. Do surgical care bundles reduce the risk of surgical site infections in patients undergoing colorectal surgery? A systematic review and cohort meta-analysis of 8,515 patients. Surgery. 2015;158(1):66-77.

24. Kao LS, Meeks D, Moyer VA, Lally KP. Peri-operative glycaemic control regimens for preventing surgical site infection in adults. Cochrane Database Syst Rev. 2009; (3):CD006806.

25. Al-Niaimi AN, Ahmed M, Burish N, Chackmakchy SA, Seo S, Rose S, et al. Intensive postoperative glucose control reduces the surgical site infection rates in gynecologic oncology patients. Gynecol Oncol. 2015;136(1):71-6.

26. Ng RR, Myat Oo A, Liu W, Tan TE, Ti LK, Chew ST. Changing glucose control target and risk of surgical site infection in a Southeast Asian population. J Thorac Cardiovasc Surg. 2015;149(1):323-8.

27. Boreland L, Scott-Hudson M, Hetherington K, Frussinetty A, Slyer JT. The effectiveness of tight glycemic control on decreasing surgical site infections and readmission rates in adult patients with diabetes undergoing cardiac surgery: A systematic review. Heart Lung. 2015;44(5):430-40.

28. Rutan L, Sommers K. Hyperglycemia as a risk factor in the perioperative patient. AORN J. 2012;95(3):352-61. 